\title{
Crying 'Wolf'? A Review Essay on Recent Wagner Literature
}

David B. Dennis

Loyola University Chicago, dennis@luc.edu

Follow this and additional works at: https://ecommons.luc.edu/history_facpubs

Part of the European History Commons

\section{Author Manuscript}

This is a pre-publication author manuscript of the final, published article.

\section{Recommended Citation}

Dennis, David B.. Crying 'Wolf'? A Review Essay on Recent Wagner Literature. German Studies Review, , : 145-158, 2001. Retrieved from Loyola eCommons, History: Faculty Publications and Other Works,

This Article is brought to you for free and open access by the Faculty Publications and Other Works by Department at Loyola eCommons. It has been accepted for inclusion in History: Faculty Publications and Other Works by an authorized administrator of Loyola eCommons. For more information, please contact ecommons@luc.edu.

\section{(c) (i) $९$}

This work is licensed under a Creative Commons Attribution-Noncommercial-No Derivative Works 3.0 License. (C) German Studies Association 2001 


\author{
Crying "Wolf"? \\ A Review Essay on Recent Wagner Literature
}

David B. Dennis

German Studies Review

\begin{abstract}
Joachim Köhler. Wagner's Hitler: The Prophet and his Disciple. Translated by Ronald Taylor. Cambridge, UK: Polity Press, 2000. Pp. 378. Cloth \$29.95.

Stephen McClatchie. Analyzing Wagner's Operas: Alfred Lorenz and German Nationalist Ideology. Eastman Studies in Music. Rochester, NY: University of Rochester Press, 1998. Pp. xiii, 262. Cloth \$95.00. Lydia Goehr. The Quest for Voice: On Music, Politics, and the Limits of Philosophy: The 1997 Ernest Bloch Lectures. Oxford, U.K.; New York: Clarendon Press; Oxford University Press, 1998. Pp. x, 237. Cloth $\$ 45.00$.
\end{abstract}

Evidently, Wagner's Hitler was intended to stir controversy, and it has worked. When released in Germany in 1997, at the same time as Gottfried Wagner's excoriating memoir of Wahnfried family life and while Goldhagen arguments still sparked, Joachim Köhler's book added fuel to the fires of Wagner debate. Based on previous work about Nietzsche's "secret" (homosexuality, in his opinion), Köhler's reputation already ranged from that of "studierter Philosoph" to "Enthüllungsjournalist," and the initial reception of his latest was likewise divided. On the one hand, German reviewers acknowledged the "staunenswerter Fleiss" with which Köhler amassed detail to support his argument: for readers unfamiliar with Wagner-critical literature of the last decade, opined one, this book relates all the juicy bits in condensed form. However, despite its utility as a "Zitatreservoir," critical consensus held that Köhler's book is less than scholarly, full of "gross inaccuracies" that would “make researchers laugh.”[1] Most telling was Joachim Fest's assessment: although Köhler grounded many of his theses about Hitler's outlook on Fest's biography, the historian carefully distanced himself from the "accusatory character" of this book.[2]

Ronald Taylor, who translated it into English, verifies the thesis of this angry work: "Köhler argues that, as Hitler was the instrument of the Holocaust, so Wagner bears a responsibility, in the same historical continuum, for Hitler. What Wagner urged in words of rabid racial hatred and incitement to political violence, Hitler turned into chilling, murderous reality" (4). In Köhler's own terms, “the man who plunged Europe into disaster was 'Wagner's Hitler' . . . . His campaign to exterminate the Jews was part of his love for Wagner. He had to hate the Jews because he loved the man who hated them" (293).

"What was in Hitler's mind?" (11) This is the primary question of Köhler's investigation, and he answers it with bravado: Hitler's goal "was certainly not to pursue a set of political aims, that is, to arrange the political and social realities of the time in the interests of the nation whose Chancellor he was. Reality meant for him the task of transforming the world into a Wagnerian drama" (270). Triggered by youthful experience of Rienzi, Hitler's obsession with Wagner's art and politics marked every aspect of his being, and most of his actions. A brief list of just some specifics in Hitler's life that Köhler identifies as Wagner-inspired will have to suffice here: fear and ruthless persecution of "traitors" (Rienzi [(28)]); theories of blood and race (Parsifal [(209-241)]); the Beer Hall Putsch (Rienzi [(180)]); writing Mein Kampf (Mein Leben [(94)]); removing Germany from the gold standard (Ring des Nibelungen [(74)]); design of party demonstrations (Meistersinger [(245)]); exterminationist anti-Semitism (Music and the Jews [(88)]); double suicide ("from Der fliegende Holländer to Götterdämmerung'[(8-23)]). Not only, in Köhler's view, were Hitler's personality and political leadership modeled on perceptions of Wagner, but the very fact that the little corporal from Austria ever came to be in a position to live out his fantasies was predicated on his Wagnerian impulse. Only with timely support from the Bayreuth circle, especially Houston S. Chamberlain, Winifred Wagner, and henchmen like Dietrich Eckhart in the Thule Society, could the unimpressive Hitler assume the self- then public image of a Wotan/Siegfried figure, complete with telling nickname: "Wolf." Their selection of this boorish non-entity as inheritor of the "master's" mantle, savior of both Bayreuth festival and German nation, was based wholly on perception of Hitler as an uncommonly fanatical Wagnerite who would do their bidding.

Above all, according to Köhler, Chamberlain provided the vicious veteran with the confidence required to impose his will to power, dictatorship, invasion, and extermination. A shell of a man, void of style or content - though full of 
hatred and ambition-Hitler defined himself and his goals only via reference to Wagner mythology, both artistic and biographical. Unlike most worshippers, though, Hitler's dreams of connecting with the idol were fulfilled in 1923 when Chamberlain, supposedly the most important living representative of his hero, deemed him successor to Wagner's throne (162-177). As Köhler puts it, "it was not some obscure religion that compelled [Hitler] to make decisions such as 'no mortal' had made before and forced upon him one last cruel resolve [extermination of European Jewry]. Nor did he make this final resolve as a politician or as a military commander, still less as the supreme representative of the German people. He made it as the man chosen to fulfill Wagner's prophecies and carry out the charge laid on him by Chamberlain" (18).

The gist of Köhler's hypotheses about Hitler's psychological dependency on Wagner is, I dare say, not particularly new: Fest and others have already identified this as a crucial element in his character. More original is the attention he pays to Hitler's habit of playing Wagnerian roles: not in the fantastic sense, as Held, alone; but literally, as performer-as Heldentenor. "His rivals talked of the fate of the German nation; Hitler sang it," Köhler observes (141), and assessments of Hitler's rants as modeled on Wagner's style-both in terms of discourse ("Under these blows the iron that runs through the German people will be forged and made as tough as steel!" [(80)]) and structure (lengthy, with "inevitable and exhausting repetition" [(93)] —-substantiate this intriguing point.

But a related argument, about the Wagnerian bases of Hitler's writing in Mein Kampf, reveals methodological problems in Köhler's work. Chapter Thirteen is largely devoted to proving that Mein Kampf is a fictionalized account of Hitler's transformation from "an unemployed nobody" into a "Wagnerian hero," full of indications that the future "Führer" adopted his world-view primarily from Wagner's works (198-208). The problem is that very few lines in the wretched book refer directly to Wagner. To be sure, general themes and much language deployed in Mein Kampf can be understood as derived from a powerful current of Wagnerism prevalent in the right wing of European culture through Hitler's lifetime. Köhler argues convincingly that Hitler's psyche was strongly influenced—or severely damaged—by this malignant strain of thought. However, analysis of neither Mein Kampf nor the handful of other explicit references Hitler made to Wagner demonstrates incontrovertibly that the composer's own texts-operatic or otherwise-served, in unadulterated form, as the sole sources of Hitler's thinking. Doubtless, Hitler was infested with notions carefully filtered and deemed Wagnerian by members of the Bayreuth circle in particular and the volkish right in general, through a process of reception that Steven Aschheim referred to as the "selective scavenging" of biographical detail for use toward (in this case, right-wing) ideological purposes.[3] Hitler clearly modeled himself on a common set of assumptions about Wagner, and Köhler documents this facet of Wagner reception richly. But whether Hitler's Wagner was indeed Wagner, or whether Wagner "bears responsibility" for the actions this construct inspired, remains uncertain-Köhler's confident claims notwithstanding.

Köhler's style, even in translation, is exhilarating. Perhaps comparable to a Wagner opera, his argumentative line overwhelms with a flood of detail addressing apparently related motifs. But beneath this passionate stream, Köhler has, also like Wagner, bent standards of (academic) composition. Mainly in his efforts to demonstrate Wagner's direct influence on Hitler's mind, Köhler practices what one reviewer termed a "highly suggestive" procedure of "splicing sources" (Zitatverknüpfungstechnik).[4] To suggest the lasting influence of Wagner's activities in 1848-9, for example, Köhler concatenates quotations and biographical data that range across Wagner's and Hitler's lifetimes: in just three pages he touches upon Wagner's (possible) bell-ringing during the uprising in Dresden, Gottfried Semper's designs for the Munich opera house, Hitler's plans for a theater in Linz, Wagner's exile in Switzerland, a 1925 conversation between Hitler and Hans Severus Ziegler, the 1938 invasion of Austria, Wagner's letters to Eduard Devrient in 1849, and statements recorded by Cosima in 1872 and 1879 (48-50). Thoroughly assessing his thematic connections requires having chronologies of both lives at hand.

Besides contextual jumps, Köhler revels in arguments following sharp linguistic turns. While insisting on the antiSemitic impulse behind a poem of 1849, for instance, Köhler cites Wagner as threatening those who "mockingly blaspheme against the living God." Though the source does not mention Jews explicitly, Köhler interprets this phrase as referring to Jewry and then states in the strongest terms that Wagner here "reserved a flaming torch for the Children of Israel" (44). To link this material with Hitler, Köhler resorts to further word play: Wagner evoked a "flaming pyre" in his revolutionary poem; Wagner was [possibly] involved with making pitch torches in 1849; Joachim Fest referred to Wagner's works as "explosive" in a biography of Hitler; therefore, this sequence implies, both Wagner and Hitler were explosive types bent on burning Jews (44). Köhler's use of Fest in this passage is representative of his additional tendency to present scholarly opinions as certainties, often in language usually reserved for observations by contemporaries: in the tower of the Dresden Kreuzkirche on 9 May 1849, “'the bell rope was close to [Wagner's] hand,' added Ernst Newman" (48) — in the nineteen-thirties! My intention is not to question any of the material that Köhler threads into his dual portrait. Careful consultation of the references confirms the accuracy of his citations, but the reader should make use of the endnotes when judging Köhler's hypotheses, especially to track the original chronology of the sources. 
As if to justify his practice of splicing citations-or reading between the lines-Köhler repeatedly asserts that the true messages of the "master's" art and politics were only discussed among Bayreuthians, including Hitler, in code. "Thanks above all to Wagner's penchant for talking in riddles" (290), but also out of fear for Jewish-led conspiracies, there was "a custom adopted in Bayreuth from the beginning, that Wagner's name should never be mentioned in connection with the 'Jewish question"' (126). Above all obedient to the Bayreuth cult, Köhler's Hitler strictly observed this rule: "The message enshrined at the heart of this program — ethereal vision later converted into horrible reality-was guarded by Hitler and his band of disciples as though it were a holy relic. References to it were cast in riddles, its real meaning shrouded in silence" (7). The ultimate, genocidal aim of Hitler's program remained secret even to other leading Nazis, according to Köhler; only fellow Wagnerians such as Hermann Rauschning were privy to the code (238-241). All others "were denied access to the real meaning of the message," Köhler insists, in a remarkable reversal of the Goldhagen thesis: "The Germans surrendered to a religion they did not know, adopting ritualistic practices they did not understand, and blissfully dying for a corpus of religious rites into which they had never been initiated" (7).

If, indeed, Wagner "expressed his thoughts in coded form, like an oracle" and "his heirs likewise disclosed their Nazi allegiance in cryptic terms" (192), Köhler's efforts to break the code would seem intriguing hypotheses. But as if he were in sole possession of a Bayreuth "Enigma machine," Köhler writes as though his transcriptions of the WagnerHitler "dialogue" are infallible, and it is the absolute tone of his style that, ironically, strains credulity. Many of his points, especially about the anti-Semitic content of Wagner's operas, address highly controversial issues. But one would never know from Köhler's text or notes that interpretations of the Nibelungen and Beckmesser as Jewish caricatures (60, 256-257), for instance, are hotly debated. Köhler has every right to his opinions, but good scholarship should resist rejecting opposing views out of hand as "based on conceptual misunderstandings" (62), and should make some use of the subjunctive when speculating.

Old-fashioned though these methodological concerns may be, it was not necessary for Köhler to manipulate his sources in order to secure the principal portion of his thesis: that the thread through Hitler's labyrinth is better followed in terms of Wagnerian fantasy then Staatsräson. But in his attempt to prove that "the inner workings of his consciousness took their bearings from the coordinates of Wagner's universe" (162), Köhler makes the more serious methodological error of disregarding complex models of reception theory operative in historiography today. Within the European cultural "horizons" of Hitler's time, Wagner was a touchstone of intellectual discourse, invoked by activists of every aesthetic, social, and political persuasion. The Bayreuthians laid first claim to his legacy, but were not unopposed: every group competing for the right to Wagner modified his image for their specific purposes.[5] Köhler assumes that Hitler derived his Manichean view of the world from Wagner, but one might also argue that the "Führer" imposed this view on the operas, simplifying complex characters, scenes, and themes. Wagner certainly lent himself to the right wing, but we must not overlook the processes of selective biography that highlighted these features of his life and work to the detriment of other facets. Otherwise, one risks slipping into acceptance of Nazi oversimplifications, reducing Wagner into the terms of Hitler's Wagner: a political man bent on destruction of the Jewish race whose music was conceived toward this end and none other.

The politicization of the German music tradition was not, of course, perpetrated by politicians and propagandists alone. As Pamela Potter and others have recently demonstrated, music scholars have often played the essential role of justifying claims to "German masters" lodged by the political left and right.[6] Among the most influential nazifiers of Wagner's legacy was musicologist Alfred Lorenz. Conductor, composer, and frequent producer of Wagner operas when Generalmusikdirektor in the service of the Duke of Saxe-Coburg Gotha, Lorenz was pensioned off as a musician after the First World War. Certain that he was, in his words, "removed by the Social Democrats to make room for a Jew," Lorenz undertook a second career in musicology with a decidedly political bent. While studying in Munich, he became a staunch supporter of Hitler and his party, voting for them from 1920 on, allowing his son to participate in the "Beer Hall Putsch," advancing Alfred Rosenberg's Kampfbund für deutsche Kultur, and registering as an NSDAP member in 1931. While earning his doctorate, then teaching at the University of Munich, Lorenz also contributed articles to various Nazi or nazified journals on topics such as music and race, music and the "Jewish question," and musicology and genealogical research (Ahnenforschung). In such writings, Lorenz sanctioned-with his newly-minted academic credentials_-direct associations between Wagner and Hitler: "I would like to pronounce that this prophet [Wagner] already carried in his heart the meaning of the National Socialist revolution, which has today become fact" (Deutsches Wesen, 1933); "In his Gesamtkunstwerk he even managed to bring about the unification of all the arts into a marvelous whole, just as Hitler did with the German people" (Wille und Macht, 1933).

With a record like this, persons unfamiliar with the ironies of the twentieth-century German music world will be surprised to learn that Lorenz's influence did not die out with him in 1939_or with his "Führer" in 1945. As Steven McClatchie relates, "the long shadow of Alfred Lorenz still hangs over the field of Wagner research" (ix). In fact, his scholarship "unquestionably forms the basis of modern Wagnerian analytical research" (171) because "all Wagnerian analysis since Lorenz is in some respects a response to his work" (xi). Recognizing Potter's thesis about the continuity of German musicology before, during, and after the Hitler era, McClatchie's Chapter Six shows that reception of 
Lorenz's analytical method has been largely “silent about Lorenz's National Socialist ties” (192), avoiding “all systematic account of these connections" (186).

The initial goal of McClatchie's study is to break this silence about Lorenz's "personal and professional relationship with National Socialism" (xii) and, as it turns out, demonstrating his Nazi affiliations is a fairly simple matter. One look at the photograph McClatchie used as cover and frontispiece-a portrait of Lorenz originally printed in the Völkischer Beobachter, fiercely sporting his party pin-is enough to convince that this was an enthusiastic Parteigenossen. Any doubts are dispelled by McClatchie's first chapter full of biographical and bibliographical evidence based on fresh archival work. However, McClatchie's intentions reach further than this. The basis of Lorenz's lasting authority in Wagner studies is by no means his collection of writings for Nazi journals, but his four-volume Das Geheimnis der Form bei Richard Wagner (1924-33) that McClatchie acknowledges as “an exhaustive, and still unsurpassed synthesis of Wagner's compositional and dramatic technique" (171). In this study of the Ring cycle, Tristan, Meistersinger, and Parsifal, Lorenz fought against notions that Wagner's music was "formless," insisting that one can perceive "poetic-musical periods" throughout the works. "Defined by such fundamental parameters as rhythm, tonality, and melody," McClatchie explains, "particularly important among these is a three-part A-B-A form, which Lorenz calls Bogen form (arch form), and the A-A-B form, or Bar form, employed by the medieval Meistersingers" (ix). Even if Das Geheimnis der Form appears free of explicit Nazi rhetoric, McClatchie firmly contends that National Socialism not only stains Lorenz's professional and political life, but severely taints his major theoretical work: "His analytical method . . . is rooted firmly in nineteenth-century philosophy and aesthetics, yet at the same time might be understood as an embodiment of National Socialist ideology. Far from being irrelevant, the ideological underpinning of Lorenz's thought is crucial for an understanding of that thought itself, and of its reception" (25).

To grasp Lorenz's analyses, and ultimately their Nazi implications, McClatchie insists that one be familiar with their theoretical background, so a large portion of this book surveys nineteenth-century aesthetic philosophy. Lorenz's ideas evolved from the late-Romantic "expressive aesthetic" (Gefühlsästhetik). Based most firmly on Schopenhauer's views of art, the expressive aesthetic privileged feeling over form, emotion over structure, will over design. Above all, musical gestures were valued as the least mediated records of emotional states experienced at the instant of creation, the most direct possible copies of will imposed by genius. From Schopenhauer through Wilhelm Dilthey, Friedrich von Hausegger, August Halm, Ernst Kurth, Hans von Wolzogen, and on, expressivists focused attention on subjective content instead of music technique. "To understand music," according to Kurth, "is to experience vicariously the flow of psychic energies which gave rise to the music in the first place" (52). "Empathetic hearing" (56), not score studying, was the expressivist watchword in the culture war against formalists like A. B. Marx, Eduard Hanslick, and Hugo Riemann, who were preoccupied with "standard schematic patterns for larger forms"-most typically, the sonata paradigm (44).

In his 1871 essay on Beethoven, fundamentally a summary of Schopenhauer's music philosophy, Wagner anointed himself champion of the expressivist camp (31). Subsequently, McClatchie demonstrates, the expressive aesthetic became "that of the Wagnerians" - the "root of all that passed for Wagnerian analysis" (61). The dominant impulse behind identifying Leitmotiven was not tracing the unfolding drama of Wagner's operas, but experiencing each as a reincarnation of Wagner's soul at the moment of inspiration. Expressivist Wagnerians immersed themselves in the music dramas not to appreciate products of the composer's genius, but to literally enfold their spirit in the will of the "master." McClatchie perceives problems within the expressive aesthetic in general. "In the light of subsequent developments in Germany, such theoretical speculation_not restricted to music theory, but as part of a certain Germanic tendency to Innigkeit_has disturbing consequences in the political sphere, particularly in its devalorization of parts apart from the wholes" (58). Lorenz's views, however, were not strictly in line with the expressivist tradition. Reacting, it seems, to music "modernists" who aligned Wagner as a forerunner of twentieth-century tendencies, Lorenz modified the expressivist approach to demonstrate that "Wagner's music was not formless; that it was, basically, tonal (and certainly was not 'atonal')" (201). Trying to reconcile the expressive and formal positions, Lorenz subjected Wagner's works to close analysis to prove that they were well-structured and (tonally) unified. His meticulous classification of Bogens and Bars throughout Wagner's oeuvre, over "pages and pages of tables, graphs, and numbers" (200), is bewildering to the non-expert, but articulately summarized by McClatchie.

Though his analyses "appear static, objective, and scientific" (200), Lorenz's goal was compromise with the Schopenhauerian approach: identifying forms, in his view, is a means of comprehending the will or inspiration behind them, not an end in itself. Ordered by impulse (literally, pulse), not rules, musical structures are by-products of the creative process, not its essence. But in McClatchie's opinion, Lorenz cannot have it both ways. "It must be admitted that Lorenz is sometimes inconsistent in his treatment of the period," he asserts: "There are passages, acts, and even operas for which a compelling case can be made for tonal organization. Yet for every unambiguous example of such tonal organization, other instances-perhaps even in the same work-can be cited where this rule does not obtain" (164). Ultimately, McClatchie holds, some of these analyses "are so general as to be at once convincing and silly" (148). 
Assessing Lorenz's particulars as convincing, silly, or both is best left to the expert reader, but McClatchie's broader point is that the effort to fortify the "master" against attacks from all sides resulted in a conflicted view of Wagner. The only way to explain Lorenz's inconsistencies, McClatchie insists, is to recognize that all of his work was inspired by proWagner sentiment. Even if, in part, "Lorenz is a formalist, his formalism is neither positivistic nor objective, for it is closely bound up with ideological and nationalistic issues: by revealing the form and logic behind Wagner's works, Lorenz in a sense validates them as echte deutsche Kunst" (201). Lorenz "employed various sorts of analytical sleights of hand" not just to "explain the diversity of Wagnerian form" (165), but to prove the fundamental point of Wagnerian liturgy: that the "master" was infallible-the great synthesizer of expressive and formalist aesthetics. It is in this sense above all that Lorenz's analytical method is ideologically compromised.

But in what sense was this prejudice "National Socialist"? To show this, McClatchie effectively cites interpretations of Nazi culture by Theodor Adorno, Walther Benjamin, Fritz Stern, George Mosse, and myself, among others: "Lorenz plays an important role in remaking Wagner into a monument to the great German tradition rhapsodized by the Nazis. By proving the unity and formal perfection of the music dramas by analysis, Lorenz helps remove the taint of 'decadence' that still clung to Wagner owing to his earlier association with Jews, liberals, modernists, symbolists, and hysterics" (207). Moreover, McClatchie leans heavily on Jeffrey Herf's concept of reactionary modernism: "By arguing that Lorenz is part of a new, modernist discipline of 'analysis' but also resistant of this move, we can tap into a stream of 'reactionary modernism' in Germany" and this "may help uncover latent ideological aspects of his analyses that mark him clearly as caught up in the cultural politics of his day" (201-202). Lorenz's theory was, therefore, Nazi because it was both "part of th[e] modernist move in analysis_-giving priority to score over sound" and "tinged by anti-modernist nostalgia" (201). In other words, the paradoxical nature of Lorenz's analysis - "irreparably rent with these conflicts" (201) — should be condemned as an erroneous construct inspired by reactionary-modernist political views: Nazism.

But were Wagner's aesthetics not paradoxical? That Alfred Lorenz was a committed Nazi who contributed to the aestheticization—or rather, Wagnerization_of the party, enhancing the auras of both its "master" and its "Führer," is undeniable and unforgivable. McClatchie's book is an important exposé of this musicological scandal. But there is some room for reservations about his premise that the inconsistencies in Lorenz analytical method were nothing but leaps of National Socialist faith. This part of the argument could only be substantiated if a single, consistent view of Wagner (as either expressivist or formalist, reactionary or modernist) were universally agreed upon. The trouble is that no such certainty about Wagner's aesthetics or character is in sight. Indeed, disharmonies in Wagner scholarship seem further from resolution today than ever, and consequently the paradoxes in Lorenz's analysis themselves do not strike relatively unprejudiced ears as completely invalid — even if, I must add, ideologically inspired.

Paradox, or in her term "doubleness," is at the heart of Lydia Goehr's book. A collection of the five lectures she gave as Ernst Bloch Professor of Music at the University of California-Berkeley in 1997, Goehr's is not primarily a work of music history or music theory, but philosophy incorporating thoughts about music-especially Wagner's-as models and examples. While her philosophical goals reach beyond the rubric of German cultural studies, many of her pointsparticularly the principle of "doubleness"- - have relevance to Wagner scholarship and reception.

Central to Goehr's lectures is the claim that "using doubleness as a technique of philosophical description" produces "theory that respects its own systematic limits" (5). Supporting "open and critical practice," doubleness "closely recalls traditional dialectics, yet it does not depend upon establishing too strong a teleological development in which oppositions are brought to their (pre)determined syntheses" (5). Goehr prefers the term "double" to "dialectical" because "it stresses that the contradictions and conflicts in which elements or claims stand to one another are not always resolved" (14). In her view, philosophical inconsistency "cannot and should not always be resolved," because conceptual discord, even antagonism "helps sustain a dynamic or open theory or practice advantaged by the presence not just of a plurality of claims, values, and ideals, but also by claims, values, and ideals that conflict with one another in progressive ways" (14). In the end, Goehr holds, her "doubleness thesis is compatible with a fundamental openness or a purposive ambivalence to the world ('let's see what the world is like')" (203).

Such statements might remind cultural historians of Tristan Tzara's "je m'en foutisme," since Goehr touches on antisystematic thought implicit in Walther Benjamin's famous dictum: "There is no document of civilization which is not at the same time a document of barbarism" (15). To Wagner studies, Goehr's derivations of the "doubleness thesis" from music philosophy and music history are most pertinent. Essential to her argument is insistence that philosophy can and should be informed by thinking about music, particularly the terms of nineteenth-century debates over musical formalism. In her view, nineteenth-century aestheticians treated formal and transcendental "accounts of the purely musical" as mutually exclusive, demanding a firm choice between them: "out of that choice emerged two very different schools of musical aesthetics_-one more empirical and gradually positivistic, the other more Romantic or metaphysical” (14). So divided, the controversy has evolved in favor of the formalist school (108). However, Goehr feels, "there was also a way of conceiving these two steps less as representing competing accounts than as representing the two different sides of the very same Romantic coin: one captured the specifically musical, or formal and empirical, dimension of music's significance, the other, its extramusical or transcendental dimension. (In this picture, the 'extramusical' ... takes 
on the connotation of something 'beyond' or 'more' rather than 'non')" (14). A more effective conception of music would respect its inherent doubleness, accepting both parts of the formal/expressive dichotomy as "jointly representing a necessary but irreconcilable opposition" (14). The resulting "position of enhanced or critical formalism" (19) combining (not synthesizing) these opposites, would promote the notion that "music means something, not just because it is a well-formed symbolic language, but because when human beings engage with this language they express something about themselves as human beings" (1).

To right the modern imbalance toward formalism, Goehr wants to "resituate the concept of the musical by shifting our emphasis from a work's form and content to music's function of expressing or voicing the inexpressible through performance" (4). To do this, Goehr revisits what McClatchie termed the "expressive aesthetics" of the nineteenthcentury. Concentrating on Schopenhauer, Goehr seeks to revive expressivism because "this mode of description turns out to be a way of protecting music from a reduction, translation, and corruption into the mundane." Addressing it "as the pure language of Will, or of free subjectivity, or of pure feeling, spontaneity, and gesture protects music from the usual range of base concepts and feelings, common judgments, and desires. Not limited by the usual systematic or scientific laws of order and meaning, music succeeds in its own unspoken terms in revealing the spiritual meaning of the world" (30-31).

The primary texts of Goehr's "revised reading of music's claim to autonomy" (4) are Wagner's theoretical writings. For Wagner, "the essence of higher instrumental music consists in expressing in tones something inexpressible in words. . . . In contrast to speaking through the understanding, the orchestra speaks the unspeakable through 'gesture' and 'feeling." Music, "he reiterated in devotedly Schopenhauerian terms, speaks to us of 'the world outside us' and 'in terms intelligible beyond compare." However, it is comprehensible to us "not through logic, but because "the message sounding in our ear is of the selfsame nature as the cry sent forth to it from the depths of own inner heart." Any language, Wagner held, "including the literal language of music itself, must be animated by the spirit of the musical if it is to succeed either directly or indirectly in expressing the inexpressible" (34-35).

Still, while "showing the dangers of losing the musical in our music," Wagner did not limit himself, in Goehr's eyes, to expressivist theory and technique. To provide an "antidote to a prevalent mode of musical thinking he believed was overly constrained by formalism," Wagner "employed two concepts of the musical." His intention was "restoring an older, metaphorical concept of the musical [Socrates' mousike] to accompany a more modern, literal one." Thus, Wagner "tried to revolutionize the practice by indulging in the antagonistic play of these oppositions" (1-2). Full comprehension of Wagner's aesthetics must therefore take into account its doubleness: blaming "the increasing impoverishment of musical meaning directly in proportion to its being cut off from its true dramatic and poetic aim," he decreed that "formalism connected to this aim was permissible; formalism for its own sake was not" (108). Perceptions of Wagner as expressivist master alone have belied the complexity of these aesthetics, which would correlate more closely with Goehr's "Janus-faced description" of the "deeply paradoxical or contradictory condition" that "formally, a work may be a purely musical work of art at the same time that, transcendentally, it can show the (extramusical) world 'in its entirety" (15).

In light of Goehr's views, it seems that an extended discussion of Alfred Lorenz's analytical methods might have made a fascinating addition to her lecture series. The "inconsistencies," "contradictions," and "logical unsoundness" that McClatchie perceives in Lorenz's assertions of form within Wagnerian formlessness seem perfect test cases for Goehr's “doubleness thesis" about Wagner's aesthetics. Moreover, McClatchie's insistence on “ideologically oriented evaluation" of Lorenz's analyses pertains to another major area of doubleness that Goehr addresses. In addition to the expressivist/formalist duality, Goehr devoted lectures to treating concepts of the "perfect performance of music" versus the "perfect musical performance" and "native" composers versus "exiled" composers as likewise "jointly representing necessary but irreconcilable oppositions." But perhaps the most controversial juxtaposition in Goehr's philosophy is that which she draws between politics and ideology. "The idea governing my interpretive scheme and methodological argument [is] that a practice (musical, political, or philosophical) is progressive when it is open, and is open when it is regulated by suitable regulative or formal ideals that have neither been overdetermined nor closed by ideological content" (37). Here she employs "'political' to refer to the formal nature of ideals and/or to the quality of underdetermination, and 'ideology' to the substantive or concrete content used to fill out these ideals and/or to the attempt to complete their determination." According to this stipulation, "the distinction between the political and the ideological marks their mutually exclusive aspects," but does not rule out their coexistence in a world view or body of work (38).

As in each of the others, Goehr uses Wagner's works as specimens for testing this doubleness thesis, trying "to unravel [his] combined metaphysical and cultural judgments by isolating what I call a progressive, political model from its regressive, ideological counterpart" (37). Regarding the composer, her intent is "to save the progressive side of Wagner's view against its regressive articulation." But she wishes to do so not by "separating his aesthetics from his politics" — the method applied by most apologists—but by distinguishing "as far as one can, his politico-aesthetic model from its crude, ideological determination" (42). 
The implications of this variation on Goehr's “doubleness thesis” for ongoing debates about Wagner's socio-political engagement-and his long-term responsibility for the results—are evident. In her opinion, the overriding "political" motive behind Wagner's artistry was linking "music's expression with human expression to maintain a connection between aesthetics, politics, and philosophy" and thereby to draw all these areas into an "endless quest or aspiration towards large-mindedness." Whenever Wagner assailed "what he took to be the overly separated academic disciplines and their associated abstracted and alienated practices"-which carry the "danger of succumbing to closedmindedness" - he "appealed to this tripartite connection" (41-42). This was the open, underdetermined side of Wagner's program - the "politics" that Goehr hopes to save.

On the other hand, when Wagner moved to "fill out those ideals" with "substantive or concrete content," he often slipped into "regressive articulation." "Duly attacking communities and cultures according to their degree of abstraction" or closed-mindedness, Wagner would put his critiques in terms of their “'bourgeois,' 'cosmopolitan,' or 'Jewish' estrangement" (42). This sometimes reprehensible "ideological” side of Wagner's output coexisted with, but was not the same as his "politics," and one should not be judged in terms of the other. "This position," Goehr holds, "allows us to say of Wagner's view, at moments when it is relevant to do so, that it went profoundly wrong whenever he filled in the ideal of the purely human with, say, substantively anti-Jewish content. But it also allows us to say that the same formal view could have been filled in differently" (130).

To relate her "doubling thesis" about Wagner's politics and ideology, Goehr devoted an entire lecture to the case of Die Meistersinger von Nürnberg. The "political" argument of Die Meistersinger, she asserts, is of sufficient metaphysical generality that it does not immediately pre-establish a clear ideological commitment" (67). Namely, "its libretto argues in favor of correct motivations for creativity and against its corruption by false ones. Genuine works of art result from correct motivation, and examples of these are supposed to be Wagner's other operas" (50). An "accompaniment to the composition of his other works" (50), Die Meistersinger "is about the protection of integrity of the individual and the community against the constant threat of prejudice, pedantry, corruption, and unsound judgment. It is about the way music as the language of escape provides a justification for life" (74). In short, Die Meistersinger "argues for the freedom to create a new art, the art of Tristan" (50). However, standing against this "politics" of free musical expression, Wagner perceived forces that "reduced inspiration to a determinate set of rules, nature to artifice, beauty to a determinate set of empirical properties, and subjective freedom to communicable convention" (76). To the extent that Wagner's opera parodied pedantry via "political assertions or 'general ideas," Goehr applauds.

While she does not confront the issue of whether or not Sixtus Beckmesser's characteristics were meant as Jewish, it is apparent that this could be taken as an example of Wagner transforming his "political assertions or "general ideas" into ideology, filling in the ideal—or here, the contrary-with "determinate . . . racist content" (36). Beckmesser is, undoubtedly, "the regressive pedant, a 'rhyme-bound sticker and paster,' conceptually confined by his craft view either to follow rules and produce good (rather than beautiful) songs, or to break rules and make a fool of himself' (58), and at this "political" level of abstraction, he is an enemy to be criticized, parodied, even pilloried. That Wagner communicated this critique by associating such problems "with what he called the modern tyranny of the French, the Viennese, the fashionable, the petit bourgeois, and the Jews" (62), is unfortunate, but less significant because part of the concrete, ideological side of his argument. Applying the "doubleness thesis" in this case means recognizing the "political" message of Die Meistersinger — a critique of pedantry and corruption—without denying the "ideological" terms he used to convey it, even if these included anti-Semitic allegory. Determining whether or not Beckmesser is a Jewish caricature, this argument implies, would be a step toward better assessing Wagner's "ideology," but it would have no effect on his "politics"—which can be distinguished from its "regressive articulation."

Taken as a whole, Goehr's lecture on Die Meistersinger revolves not around Beckmesser but Walther von Stolzing: "the inspired artist who works through subjective sentiment and the inspiration of pre-willed dreams," symbolizing "the universal, free, and anti-bourgeois subject to whom, in matters of creativity, it is inappropriate to attach empirical or 'prejudicial' attributes" (57-58). For Goehr, the main message of the opera is embodied in this character, and consideration of Walther's reception history may illuminate the broader import of her "purposive ambivalence," despite some potentially troubling ramifications. Focusing on Hans Sachs, "the sobering teacher who recognizes the Romantic difference between art and craft, but understands the sorts of constraint to which art must nevertheless remain subject" (58), Nazis highlighted principles of discipline and honoring past masters, largely overlooking the character who would combine (but not synthesize) these strictures with free expression to produce "art of the future." It was partly by deemphasizing Walther-or rather, his symbolic role in the aesthetics of the future-that Nazis minimized Wagner's modernist tendencies and reputation. On the other hand, since 1945 some have tried to draw attention away from Walther (and Sachs) toward Beckmesser, interpreted as stereotypical Jew. In doing so, Wagner's critics have ironically achieved the same end as that perpetrated by the Nazis: undermining the progressive aspects of his paradoxical legacy. These, as Goehr argues, were conveyed "by indulging in the antagonistic play of oppositions": Wagner left "gaps"between form and expression, aesthetics and ideology, respectability and decadence, love and sexuality, nationalism and racism-and it is precisely such spaces of irresolution, inconsistency, or illogic that once fascinated futurists because 
these "doublenesses" seemed to correlate with the asymmetries of modern life. Both Nazis and their opponents have tended to suppress the multi-faceted nature of the Wagner complex, fitting him into single-minded terms. In the spirit of modernists who resisted fascist ideologies with "dynamic or open theory," Goehr reminds us not to think as Hitler did-about Wagner, or anything else: "I think one should take from Wagner less his confidence than his Faustian warning that each of us, at every moment, is in danger of succumbing to closed-mindedness" (41). Walther, then, or "Wolf"? Every listener will always have the responsibility of choosing, or deciding not to choose.

[1] "Flucht ins Ungenaue," Focus Magąin, 10 March 1977. See also Jürgen Kesting, "Weh, du bist ein Wagner!" Die Woche, 7 March 1997.

[2] Joachim Fest, "Wagners eigenwilliger Vollstrecher," Frankfurter Allgemeine Zeitung, 18 July 1997.

[3] See Steven E. Aschheim, The Nietzsche Legacy in Germany, 1890-1990 (Berkeley: University of California Press, 1992).

[4] "Bücher," Neue Zürcher Zeitung, 12 April 1997.

[5] See William Weber, David C. Large, and Anne Sessa, eds., Wagnerism in European Culture and Politics (Ithaca: Cornell University Press, 1984).

[6] See Pamela M. Potter, Most German of the Arts: Musicology and Society from the Weimar Republic to the End of Hitler's Reich (New Haven, London: Yale University Press, 1998) and David B. Dennis, Beethoven in German Politics: 1870-1989 (New Haven: Yale University Press, 1996). 